This is an electronic reprint of the original article. This reprint may differ from the original in pagination and typographic detail.

Author(s): Stutz, Christian; Sachs, Sybille

Title: $\quad$ Facing the Normative Challenges : The Potential of Reflexive Historical Research

Year: $\quad 2018$

Version:

Please cite the original version:

Stutz, C., \& Sachs, S. (2018). Facing the Normative Challenges : The Potential of Reflexive Historical Research. Business and Society, 57(1), 98-130.

https://doi.org/10.1177/0007650316681989

All material supplied via JYX is protected by copyright and other intellectual property rights, and duplication or sale of all or part of any of the repository collections is not permitted, except that material may be duplicated by you for your research use or educational purposes in electronic or print form. You must obtain permission for any other use. Electronic or print copies may not be offered, whether for sale or otherwise to anyone who is not an authorised user. 


\title{
Facing the Normative Challenges: The Potential of REFLEXIVE HiSTORICAL RESEARCH
}

\author{
Christian Stutz * \\ University of Jyvaskyla, Department of History and Ethnology \\ HWZ University of Applied Sciences in Business Administration Zurich, Institute for \\ Strategic Management: Stakeholder View \\ Sybille Sachs \\ HWZ University of Applied Sciences in Business Administration Zurich, Institute for \\ Strategic Management: Stakeholder View \\ University of Zurich, Department of Business Administration
}

* Correspondence to: HWZ University of Applied Sciences in Business Administration Zurich, Lagerstrasse 5, 8021, Zurich, Switzerland. E-mail: Christian.stutz@fh-hwz.ch

Forthcoming at Business \& Society. Special issue "Quants and Poets: Advancing methods and methodologies in B\&S research" 


\title{
Facing the Normative Challenges: The Potential of Reflexive Historical Research
}

\begin{abstract}
This article explores methodological problems of qualitative research templates, i.e., the Eisenhardt and the Gioia case(s) study approaches, which are relevant for the business and society (B\&S) scholarship and outlines a reflexive historical research methodology that has the potential to face these challenges. Building on Hans-Georg Gadamer's philosophical hermeneutics, we draw critical attention to qualitative B\&S research and frame the methodological problems identified as the normative challenges of qualitative research: i.e., to productively deal with both the researchers' norms and the research subjects' norms. We then introduce the reflexive historical case study (RHCS), a distinct research strategy to face normative challenges based on philosophical hermeneutics and the interpretive tradition of studying organizations. This research approach aims at theory elaboration while its mode of enquiry is reflexive. By explicating three of its key characteristics and using a case example to illustrate our approach, we demonstrate how B\&S scholars can benefit from the "temporal filter" of the historical lens and from reflexive concerns about the nature of theory and empirical material. To tap the potential of historical research, we finally envision a research program for studying issues and debates associated with B\&S scholarship.
\end{abstract}

Keywords: Historical Research; Qualitative Research Methodologies; Theory Elaborating; Stakeholder Theory; Corporate Social Responsibility 
Since the very inception of business and society $(B \& S)$ research, scholars have been encouraged to make use of multiple modes of investigation and a variety of disciplinary lenses to deepen the field's knowledge (Crane, Henriques, Husted, \& Matten, 2016; Donaldson \& Preston, 1995; Scherer \& Palazzo, 2007; Wicks \& Freeman, 1998). Surprisingly, the historical lens is rather underutilized when it comes to issues and debates associated with the $B \& S$ agenda, despite a recent "veritable explosion of interest in history-work" (Weatherbee, McLaren, Mills, 2015, p. 4) in the broader management field (see Kipping \& Üsdiken, 2014; Maclean, Harvey, \& Clegg, 2016; Rowlinson, Hassard, \& Decker, 2014; Vaara \& Lamberg, 2016; Wadhwani \& Bucheli, 2014). Although management scholars have recognized the potential of historical research for quite some time now (Kieser, 1994; Zald, 1993), there are only a few historical studies that contribute to debates within the B\&S research agenda (Lamberg, Skippari, Eloranta, \& Mäkinen, 2004), but they mostly do not aim to produce theoretical knowledge (Carroll, 1999; Carroll, Lipartito, Post, \& Werhane, 2012; Marens, 2013). Given the anticipated potential of historical research in the B\&S field (Husted, 2015), we think this evident dearth is due to a lack of practical guidance as to "why" the B\&S community should consider a historical lens and "how" scholars should use it. This article addresses this twofold task.

We further establish the "why" by arguing that a reflexive use of history allows scholars to confront and deal with what we call the normative challenges of qualitative $\mathrm{B} \& \mathrm{~S}$ research. To develop this insight, we start from the premise that most scholars in the B\&S field share an aspiration for "grander aims" (Wry, 2009, p. 151), namely to (re)shape business in ways to make a difference in society (Freeman, Harrison, Wicks, Parmar, \& de Colle, 2010; Sachs \& Rühli, 2011; Scherer, Palazzo, \& Matten, 2014; Walsh, Weber, \& Margolis, 2003). We argue that this normative agenda proves to be full of pitfalls when scholars employ standard qualitative research templates designed for the epistemic objective to generate theoretical knowledge. 
In particular, we demonstrate the limitations of the so called positivist Eisenhardt (Eisenhardt, 1989) and the constructionist Gioia approach (Corley \& Gioia, 2004; Gioia, Corley, \& Hamilton, 2013) that Langley and Abdallah (2011) presented as the two prime methodological "templates" for qualitative research within management and organizational studies (MOS). Even though research that builds on these templates tends to present its arguments in different paradigmatic terms (Hassard \& Cox, 2013), they both represent variants of inductive case(s) study research that aims at generating novel theory or models in a data-driven manner (Eisenhardt, Graebner, \& Sonenshein, 2016; Ketokivi \& Choi, 2014). Although both templates are valid approaches and have their own merits, we argue that, when it comes to the grander aims of the normative B\&S agenda, they are limited in important ways.

First, these templates provide scholars with inadequate resources to grapple with the human dimension of reasoning in the social sciences. We call this the normative challenge to deal with researchers' norms. Scholars following either one of those templates - regardless of the different underlying onto-epistemological ground assumptions-are compelled to commit to the scientific realist view of studying organizations (Mantere \& Ketokivi, 2013). In this view, researchers proceed in a computational manner from empirical grounds to a set of theoretical claims (Mantere \& Ketokivi, 2013), and this in effect constrains scholars to disclose their own norms, values and beliefs.

Secondly, scholars guided by those templates are at risk of not making use of the empirical context they are studying to challenge their ever-present presuppositions about the phenomenon of interest (what we call the normative challenge to productively deal with research subjects' norms). Other scholars have noted that inductive research risks falling prey to merely confirming what scholars expect to see (Alvesson \& Kärreman, 2007; Ketokivi \& Choi, 2014): that is, the inability to make use of the empirical context in order to go beyond the taken-for- 
granted or preconfigured assumptions of "fashionable trends" (Kieser, 1994) in academic discourse.

In this paper we unveil and explain the pitfalls that emerge from those challenges by building on the philosophy of Hans-Georg Gadamer (1900-2002). ${ }^{1}$ Gadamer's philosophical hermeneutics is concerned with the act of understanding and grapples with its implications for the application of methods in the social sciences (see Barrett, Powley, \& Pearce, 2011; Miller, 2005; Prasad, 2002, for overviews relevant for MOS). Although philosophical hermeneutics sporadically served organizational scholars as methodological guidelines for their qualitative inquiry (Heracleous \& Barrett, 2001; Phillips \& Brown, 1993), its epistemological implications remain "mostly ignored" or "only partial[ly]" acknowledged (Prasad, 2002, p. 13). We acknowledge that Gadamer's philosophical view especially considers the potential of "history" to address both the researchers' and research subjects' norms in the process of producing novel knowledge.

For this reason-moving from "why to do history" to "how to do history"-, we deliberately build on Gadamer's thinking and propose a novel historical research strategy that we call the reflexive historical case study (RHCS). Three key characteristics distinguish it: (1) RHCS aims to reflect on, challenge and refine existing theories. As a means for this epistemic aim, the research process is reflexive (Hassard \& Cox, 2013). This methodological basis acknowledges the human reasoning context of scholars and has reflexive concerns about the nature of theories and empirical material. The methodology, then, benefits (2) from the virtues of, but equally reflects upon the limits of, naturalistic empirical material. The historical approach, finally (3), makes use of empirical contexts in the temporal past to challenge the scholars' preconceptions embedded in their contemporary place and time in order to produce novel understandings. 
By following recent literature on history in MOS, we do not aim to explicate history on the basis of a "definitive, unitary statement of historical method" (Rowlinson et al., 2014, p. 252). The burgeoning literature demonstrates that historical research appears in a complex variety of alternative approaches, which, if they have anything in common at all, it is that they draw "extensively on historical data, methods and knowledge" (Maclean et al., 2016, p. 609). Even hermeneutics, sometimes reduced to an analytical tool and portrayed as one of the basic methods of historians (Kipping, Wadhwani, \& Bucheli, 2014), is only one possible philosophical underpinning of historical research amongst many others, such as the realist scientific and the post-structuralist stance (Vaara \& Lamberg, 2016). Given the vast assortment of alternative onto-epistemological and methodological assumptions, we adopt a hermeneutical approach to history and render RHCS distinct from other historical approaches for the purpose of grappling with a specific problem, the normative challenges.

Thus, the purpose of this article is to demonstrate why and how B\&S research should consider a historical lens and, more specifically, a hermeneutical approach to history. By making this argument, we aim to make several contributions to B\&S scholarship. In particular, we contribute to the development of methodological knowledge in the B\&S field and introduce and develop a particular type of history to B\&S scholarship. However, it is important to note that we perceive the historical lens as complementing, not substituting, the variety of disciplinary lenses and methodological approaches already employed within the B\&S agenda. We believe that, if in a field a wide range of legitimate research styles and alternative ways of thinking and writing are appreciated, its "chance of more creative, imaginative and readable research being produced and published" increases (Alvesson \& Gabriel, 2013, p. 254). Finally, while this paper focuses on the reflexive potential of history in the B\&S field, many of our points also apply to management and organizational research more generally. 
The paper is structured as follows. In the first section we clarify the normative challenges and identify a set of potential pitfalls pertaining to qualitative B\&S research. Second, we contextualize our conception of history within recent approaches to history in MOS and outline three key characteristics of the reflexive historical case study approach that have the potential to confront and deal with the normative challenges. We illustrate those three characteristics by referring to one of our recent studies, which we call here the "Political Firm Case". In the final sections we propose possible avenues for future research and discuss the limits of the proposed methodology.

\section{Exploring the Normative Challenges}

In this section we explore the two normative challenges. We first turn our attention to HansGeorg Gadamer's conceptual cornerstones of understanding.

\section{Main Conceptual Ideas to Address the Normative Challenges}

The philosophical hermeneutics by Gadamer is built on the intellectual labor of Martin Heidegger (1889-1976), Wilhelm Dilthey (1833-1911) and others and further developed in an exchange with the critical philosopher Jürgen Habermas (b. 1929) and Paul Ricœur (19132005). Gadamer is especially concerned with the constitutive factors involved in the process of understanding (Prasad, 2002). Three main conceptual ideas about the nature and process of understanding can be distilled from his main opus "Truth and Method" (Gadamer, 2013; originally published in 1960 as "Wahrheit und Methode"). Their epistemological implications will address and clarify the normative challenges of qualitative research (see for the following also: Prasad, 2002). 
Gadamer (2013) conceptualizes understanding and interpretation, terms that he uses interchangeably, as context-dependent. In Gadamer's view, researchers cannot perceive meaning objectively and directly, but their interpretation is always influenced by the social practices and "traditions" in which they are embedded. In Gadamer's (2013) conceptual language, the interpreters are bound to their "hermeneutic horizons" constituted by "prejudices", i.e., their particular cultural, political, aesthetic or ethical beliefs embedded in the historical time and place (Prasad, 2002). Gadamer (2013) then uses the metaphor of a "dialogue" to conceptualize the process of understanding. In this view, the meaning of a text emerges through a conversation between the researchers and the text (i.e., research data or an empirical instance studied). Accordingly, interpretation is not a unidirectional acquisition but a situated participation in the tradition to which the text belongs (Prasad, 2002).

Derived from these conceptual ideas, Gadamer (2013) criticizes the ambition of "empathetic understanding" (see Prasad, 2002). Interpreters will always fail to understand the intended meaning of a text due to the situated and participatory nature of understanding. Accordingly, the meaning of a text is not fixed: It goes beyond the original intention. As a consequence, the process of understanding cannot be described "merely [as a] reproductive but always [as] a productive activity as well" (Gadamer, 2013, p. 307). Ultimately, scientific understanding is not about "understanding better, either in the sense of superior knowledge because of clearer ideas or in the sense of fundamental superiority of conscious over unconscious production"-instead, "it is enough to say that we understand in a different way, if we understand at all" (Gadamer, 2013, p. 307; italics in original).

Gadamer's philosophical view of understanding has important epistemological implications that challenge the epistemic virtues of objectivity and truth of the classical philosophy of science. In the following paragraphs, we examine two epistemological implications that each 
result in one of the two normative challenges. To begin with, we explain the normative challenge that deals with the researchers' norms and then move on to untangling the normative challenge to productively deal with the research subjects' norms. In each case, we address the potential pitfalls for qualitative research by highlighting striking examples of qualitative research published in Business \& Society (see the appendix for more detailed information about the sample of 52 qualitative studies we considered).

\section{The Normative Challenge that Deals with the Researchers' Norms}

The first epistemological implication relevant for the B\&S community draws on Gadamer's rejection of the idea of generating knowledge from an objective stance. This rejection implies that the knowledge produced by an academic field is prescribed and coined by the expectations, values and presuppositions of both the individual scholars and the respective research community (see also Alvesson \& Kärreman, 2011). In the B\&S context, Rost and Ehrmann (2015) confirmed this implication by scrutinizing the corporate social responsibility (CSR) and corporate social performance (CSP) debate: They concluded that B\&S scholars were biased to report favorable findings that meet the community's expectations, that is, that CSR pays off. In the realist paradigm, normative research can thus be questioned due to its potential to be biased towards the findings (Ketokivi \& Mantere, 2010). However, Gadamer (2013) stresses that these kinds of "prejudices" are not obstacles, but necessary conditions of all understanding. We will argue below that both the Eisenhardt and the Gioia template conceal the context-dependent nature of all scholarly understanding.

The computational view on reasoning. Both the Eisenhardt and the Gioia template struggle to acknowledge the human context of scientific knowledge production. As defining characteristics, research guided by these inductive templates makes a tremendous effort to demonstrate the "links between the data and the induction of [...] new concept[s]" (Gioia et 
al., 2013, p. 4) to reach a "theory which closely fits the data" (Eisenhardt, 1989, p. 541). However, as Ketokivi and Mantere (2010) have argued, induction, on which both templates rely, is a philosophical dilemma: A theory does not logically emerge from repeated observation. To address but not solve the dilemma, both templates use the strategy to emphasize the computational manner in describing their research practice (Mantere \& Ketokivi, 2013). In contrast to Gadamer's cognitive view of the process of understanding, the computational view appeals to following explicit scientific rules and guidelines for justifying inductive arguments (Mantere \& Ketokivi, 2013). By relying on the realist scientific stance, the templates stress "researcher invariance", i.e., any researcher would discover that the same generalization emerges from the data (Ketokivi \& Mantere, 2010).

This description of qualitative research practice, however, is unrealistic (Ketokivi \& Mantere, 2010). Gadamer (2013) stresses that research is always done from a particular point of view: It will never reach an objective, i.e., a value-free, state. On the contrary, if scholars neglect to reflect their specific values, the research endeavor remains inevitably political, as Ghoshal (2005) points out. According to Ghoshal (2005), it was the unquestioned set of unfavorable core assumptions in management research that led to the corporate crisis in 2001. Ghoshal (2005) calls it the self-fulfilling prophecy effect of theorizing. From Ghoshal's seminal paper, we thus derive the pitfall of (inadvertently) crafting political narratives even when researchers affirm to be objective.

Political effects in theorizing. B\&S scholars are invited to reflect on the interests their theories serve. For example, Heugens, van den Bosch, and van Riel's (2002) positivist study on stakeholder engagement promotes two different narratives that might influence practice. On the one hand, their study encourages firms to adopt the practice of stakeholder engagement according to the B\&S agenda. In this vein, Heugens and colleagues (2002) demonstrate the firms' "very concrete competitive benefits from building mutually enforcing relationships with 
their external stakeholders" (Heugens et al, 2002, p. 57). On the other hand, the study also tells a subtler story. It legitimizes the introduction of genetically modified products by the Dutch food industry in the 1990s. Heugens and colleagues (2002) do so by (most likely unconsciously) tracing the events according to the meta-narrative of scientific progress (Boje, 1995): The industry, an agent of scientific progress, strives for continuous improvement for the good of all. As some "unbridgeable [partners]" are "against biotechnology" (Heugens et al., 2002, p. 53), the industry has to stem them by continuously providing "factually correct information" (id., p. 47). With this subtext, the study (inadvertently) supports the interests of the powerful food industry in a political struggle not yet settled in the European context.

To sum up, research guided by both templates is at risk of failing to acknowledge or even recognize the human dimension of scientific reasoning. As a result, scholars might inadvertently craft political narratives, based on unreflected assumptions. Zald (1993, p. 524) has argued before that the realist stance is value-free only by appearance and leads scholars "to lack a nuanced base for the discussion of value choice". We will follow Gadamer (2013) who emphasizes the importance of acknowledging the researcher as an active reasoner.

\section{The Normative Challenge that Deals with Subjects' Norms}

The second epistemological implication is derived from the fact that a new kind of knowledge should emerge from the dialogic process between the researchers' preunderstandings and the empirical context. In this respect, Gadamer (2013) distinguishes "productive" prejudices from "false" ones, where the former are defined as those that lead to understanding and the latter are those that lead to misunderstanding. According to Gadamer (2013), the problem of understanding is that researchers cannot sort the false prejudices out in advance. This differentiation can only be realized when scholars encounter a hermeneutic context whose meaning challenges the 
truthfulness of their prejudices (Prasad, 2002). This encounter is the condition in which understanding can occur: Understanding is achieved when the scholarly "productive" prejudices are reconciled with the research subjects' prejudices. Gadamer (2013) refers to this as the "fusion of horizons".

However, other scholars have noted that it is challenging to explore an empirical context and really remain open to being surprised by it (Alvesson \& Kärreman, 2007; Ketokivi \& Choi, 2014). Or in other words, scholars are at risk of reinforcing their "false" prejudices. We call this challenge dealing productively with the norms and beliefs of the research subjects, in other words, their hermeneutic context, as we explicate below.

The positivist template and the research subjects' norms. The positivist Eisenhardt template seeks to "understand each [research] case individually and in as much depth as is feasible" (1989, p. 539). However, Dyer and Wilkins (1991) have argued in their rejoinder to Eisenhardt (1989) that the Eisenhardt template encourages scholars to uproot their research subjects from their context. This uprooting is necessary in order to establish timelessness and universal generalizability. In our sample of B\&S articles, Näsi and colleagues (1997), for example, have stressed the fact that they studied non-American companies - an underrepresented setting in B\&S research at the time. The idiosyncrasies of their research setting, the forestry industry of Finland and Canada, however, has had no impact on the results of the study. The particular context, if considered at all, is reduced to a mere factor that can be externalized (McLaren \& Durepos, 2015).

A positivist approach to context has far-reaching consequences for the ability of scholars to deal with the research subjects' norms. In an attempt to generate universal theory, scholars are at risk of committing "violence [against] the integrity of text" (Prasad, 2002, p. 21). In Gadamer's view, scholars who decline to participate in the hermeneutic horizon of the research subjects fall prey to "forc[ing] the text to fit into the straitjacket of the[ir] own prejudices, 
categories, and constructs" (Prasad, 2002, p. 21). To illustrate this argument, we focus on Butterfield and colleagues' (2004) positivist study on stakeholder collaboration. By evaluating the influence factors on the success of collaborations, they (2004, p. 186) state the following: "Not surprisingly, the interviewees once again perceived leadership (Category 47) as being important, but we were again interested to find that the interviewees viewed other moderating factors as being more central to alliance success than leadership". Here, without contesting the merits of the highly cited study, the question arises to which extent they render the informants' statements as objective facts rather than consider them answers to specific questions asked in an interview (see also Potter \& Hepburn, 2005, on methodological pitfalls of the use of interviews).

The constructionist template and the research subjects' norms. The social constructionist ground assumptions underlying the Gioia template offer the scholars more appropriate guidelines to deal with the research subjects' norms. In contrast to positivist research, scholars employing the Gioia template are intrinsically entangled with the norms of their research subjects, since they aim to grasp their informants' values, intentions and interpretations (Gioia et al., 2013, p. 6). However, scholars' capacity for empathetic understanding is limited (Prasad, 2002), as scholars and research informants share their deep embeddedness in historical time. Gadamer (2013, p. 288-9) puts the limitations straightforwardly: "The self-awareness of the individual is only a flickering in the closed circuits of historical life", i.e., the hidden prejudices make "us deaf to what speaks to us" (id., p. 282).

A study by Cook and Barry (1995), who extensively cite Dennis Gioia's earlier empirical work in the method section, might be an illustrative example. After a careful analysis of the study, we suggest it illustrates the "fore-meanings that occupy the interpreter's consciousness" (Gadamer, 2013, p. 306). As 20 years have passed since its publication, it is fair to say 
that Cook and Barry's research endeavor appears to be influenced by some unnoticed prejudices. The tacit libertarian mindset broadly circulating in the "land of the free" (cf. Schlesinger, 1999) clearly preconcerts the cast appearing in their study on small businesses' interaction with governmental policymakers. In the subtext of their paper, the role of the villain is assigned to the government "that seeks greater control over the small firm - through more stringent environmental laws, anti-discrimination rules, increased efforts at workplace safety, and so on" (Cook \& Barry, 1995, p. 341). By studying the attempts of small business firms from this perspective, it is not surprising that they "often found stories characterized less as epic heroes' journeys and more as tales of the 'hapless victim' or the 'Lilliputians versus Gulliver'.” (id., p. 340). With Gadamer (2013, p. 296) we can take a step back and recognize that the theme and object of research are actually constituted by the unnoticed prejudices, which preconfigure the production of any knowledge. In this sense, Kieser (1994, p. 610, italics added) has argued that the scholarly "identification of actual organizational problems and of their appropriate remedies" is often shaped by " fashionable' trends in organization theory and practice".

To sum up the second normative challenge, the pitfall in using the templates is that scholars might fail to go beyond preunderstandings in contemporary discourse (Kieser, 1994). Preunderstandings, either theoretical or other beliefs circulating in a specific historical context, can unconsciously guide research. We will follow Gadamer (2013, p. 309) who points towards the creative role of temporal distance that serves as a filter in order to make scholars' contemporary prejudices more self-evident.

\section{Key Characteristics of the Reflexive Historical Case Study}

This section outlines a historical research strategy we call reflexive historical case study (RHCS) that allows scholars to confront and deal with both the researchers' and research subjects' norms. The RHCS constitutes a novel approach to studying organizations and rests on 
two pillars: The recent methodological knowledge about doing history in MOS (Maclean et al., 2016; Rowlinson et al., 2014; Vaara \& Lamberg, 2016; etc.) and the interpretive research tradition to study organizations, which is also influenced by Gadamer's thinking (Alvesson \& Kärreman, 2007; Alvesson \& Sandberg, 2011; Mantere \& Ketokivi, 2013). We first contextualize our approach to history by clarifying it according to Maclean and colleagues' (2016) typology of four conceptions of history. We then explain three key characteristics that constitute our proposed methodology, relying on Gadamer's philosophical hermeneutics and methodological literature from both historiography and interpretive research in MOS.

\section{Alternative Approaches to History}

In a recent synthesis, Maclean and colleagues (2016) classify historical approaches in MOS through a matrix based on the intersection of two axes. The first axis describes the purpose or epistemic aim of the research attempt and the second evaluates the mode of enquiry that guides the research process as a means for the respective end. The resulting matrix reflects the following four conceptions of history: history as evaluating (deductive theory testing), history as conceptualizing (inductive theory generation), history as explicating and history as narrating (both employ forms of abductive reasoning, but not explicitly aimed at theorizing). We have chosen history as conceptualizing as the basis of our proposed methodology, for reasons discussed below.

Maclean and colleagues (2016) distinguish the conceptualizing version of history by referring to the two dimensions introduced above. Its purpose is conceived as enabling the exposition or substantiation of ideas, constructs and theories. Furthermore, this explicit interest in engaging with theories differentiates history as conceptualizing from other historical approaches that favor the implicit embedding of theoretical ideas in the crafting of a historical 
narrative: Namely, from history aiming at revealing the operation of transformative social processes (history as explicating) and explaining the origins of contemporary phenomena (history as narrating).

Referring to the second dimension, mode of enquiry, history as conceptualizing is distinct due to its narrative research process. This mode of inquiry accomplishes its epistemic aim by expressing theoretical ideas in a narrative way, thus remaining "embedded within the story being told (O'Connor, 2000)" (Maclean et al., 2016, p. 612). The evaluative alternative, in contrast, seeks to engage with theory by following a scientific theory testing mode of enquiry. In combining those two criteria, the value of history as conceptualizing resides in "generating new theoretical constructs" (Maclean et al., 2016, p. 614), thereby paralleling the inductive theorizing efforts of both the Eisenhardt and the Gioia template.

Based on history as conceptualizing, in the following, we discuss three distinct key characteristics that we consider useful to confront and deal with the normative challenges. Each of the following three paragraphs is devoted to one of the three key characteristics. Table 1 provides an overview of the similarities and differences of both the positivist Eisenhardt and the constructionist Gioia template. To illustrate each key characteristic throughout the paragraphs, we elaborate on an example of our recent research (Stutz, 2016), called the "Political Firm Case" here.

Insert table 1 about here

Introducing the Political Firm Case. The Political Firm Case is part of a comprehensive historical research project that studies a firm's purpose and its interactions with society throughout historical times. The firm under examination is the Swiss multinational Landis \& Gyr (LG), which was a large family-owned and export-oriented manufacturer of measuring 
instruments. In our explorative research we studied this company in the historical period of the Cold War (Table 2 in the appendix indicates some key facts about LG and Switzerland during the period studied). In the empirical instance, which we call here the Political Firm Case, LG made the decision to no longer maintain its relations to customers behind the Iron Curtain and leave the respective markets. This, from today's point of view, rather surprising decision was related to the suppression of the Hungarian uprising of October 1956 by Soviet troops, which subsequently gave rise to sharp reactions from the Swiss civil society that declared its solidarity with the Hungarian people. In our contextualizing research attempt, we soon learned that conservative and anti-communist pressure groups campaigned to break off all Swiss relations to the communist East long before the crisis. These campaigns attacked the official Swiss foreign policy that was based on the long-standing principle of neutrality and brought an issue to the political arena for export-oriented Swiss companies (i.e., to stop Eastern trade). This initial finding motivated us to pursue the question of why LG was susceptible to this public issue while most other firms continued pursuing regular business practices. From a theoretical standpoint, we used this case to examine the presuppositions of the recently introduced strategic cognition view of issue salience and firms' responsiveness (Bundy, Shropshire, \& Buchholtz, 2013). This theory, contributing to, and partly departing from, the literature on stakeholder salience (cf. Mitchell, Agle, \& Woods, 1997), describes the cognitive mechanisms that drive firms' actions in response to issues that stakeholders of the firms raise or the general public demands from the firms.

In this article, we use this case as an illustration to illuminate the key characteristics of RHCS. For a more detailed discussion of the case, we refer to Stutz (2016). Figure 1 shows the chronology of the unfolding events on the organizational, national and international level of analysis. 
Insert Figure 1 about here

Key Characteristic No. 1: A Reflexive Approach to Theories

RHCS aims to reflect on, challenge and refine theories. As a means for this epistemic aim, the research process relies on abductive reasoning, in the sense of Gadamer, "where researchers seek — through a dialogue between their own preunderstanding and the empirical data — a new understanding of theory through an evolution of their own understanding" (Mantere \& Ketokivi, 2013, p. 82). In this paragraph we bring forth RHCS reflexive concerns with the nature of theories, which allows acknowledgment of the researchers' norms and the ever-present prejudices.

Theory as prejudice. Both the Gioia and the Eisenhardt template refer to theories similar to research that employ a quantitative research design: i.e., propositions that link key concepts (Gioia et al., 2013, p. 10). Following the logic of inductive reasoning, both templates burden the scholars with the "ideal of [a] clean theoretical state" (Eisenhardt, 1989, p. 536, see also Gioia et al., 2013, p. 12) when starting case research, neglecting the influence of unnoticed prejudices on scholars. The approach of RHCS, in contrast, follows ideas of the interpretive research tradition in MOS that has incorporated some philosophical ideas of Gadamer and others (Alvesson \& Kärreman, 2007; Alvesson \& Sandberg, 2011). Critical of the realist scientific paradigm, this literature emphasizes that all knowledge arises from a prejudged point of view, entangled with values and interests (Putnam, 2002). By relaxing the status of knowledge in this way, Alvesson and Kärreman (2007) bring forth an understanding of theories similar to Gadamer's notion of the hermeneutic horizon that is constituted by prejudices: Theories equip scholars with "a line of reasoning, a metaphor, or other tools that give us a sense of what to expect" (Alvesson \& Kärreman, 2007, p. 1278). To provide such a starting point for research, RHCS 
advises scholars to consult a broad range of theories and develop a set of presuppositions necessary for hermeneutic understanding.

The prejudice for the Political Firm Case. For our research endeavor that produced the Political Firm Case, we selected the stakeholder salience literature as the debate we wanted to contribute to, which is one of the core debates of the stakeholder theory (Freeman et al., 2010; Laplume, Sonpar, \& Litz, 2008). In this debate, Bundy and colleagues (2013) have redefined stakeholder salience and departed from the initial theory of Mitchell and colleagues (1997) and the subsequent stream of literature. They changed the unit of analysis from assessing external stakeholder characteristics (such as power, legitimacy and urgency) to the organization's "cognitive structure" (or rather interpretation systems), proposing it influences and directs managerial interpretations of stakeholder issues. By using Bundy and colleagues' (2013) conceptualization as an initial illumination of our case, we developed the expectation that LG engaged with the public issue guided by the norms and values held in the particular organization. In the course of our research, we then reconsidered the preconceived theoretical explanation provided by Bundy and colleagues (2013).

\section{Key Characteristic No. 2: Reflexive Concerns with Naturalistic Empirical Material}

As the second key characteristic, RHCS has a strong preference to make use of empirical materials that come to scholars "from the time period of interest, ideally from actors involved in the events and incidents under study" (Lipartito, 2014, p. 285). These empirical materials, called primary sources by historians, meet the criterion of naturalistic data, that is, that "the activity of being recorded would have happened as it would have anyway" (Potter \& Hepburn, 2005, p. 301). In what follows we discuss RHCS' reflexive concerns with its empirical material, which renders the potential of historical research to deal with the research subjects' norms. 
The nature of historical sources. In the course of the "linguistic turn" in history, theorists of historiography questioned the epistemological status of sources and thereby challenged the positivist truth claims that objective knowledge about the past can be achieved (Hansen, 2013). By adopting this caution about the nature and limits of empirical material, RHCS approaches empirical materials in a different way than the well-known research templates. The Eisenhardt approach is, as discussed, at risk of considering the statements of its informants as objective facts. Also in constructionist research, Gioia and colleagues (2013, p. 3) convey their informants as "'knowledgeable agents', namely, that people in organizations know what they are trying to do and can explain their thoughts, intentions, and actions". RHCS stresses the opposite. Rather than assuming knowledgeable agents, RHCS characterizes informants by a more holistic conception of the human being, stating that we are dealing with everyday life people who are "looking forward into buzzing alternatives, armed with fragmentary information, rule-of-thumb analogies, and incomplete knowledge" (Scranton, 2014, p. 68). In other words, the informants are bound to their hermeneutic horizons (Gadamer, 2013).

In order to study everyday lives, the main empirical materials are naturalistic data and not interview data, which are mainly used in the prime templates. In contrast to interview data, which is often only able to reveal issues towards which scholars steer the conversations (Potter \& Hepburn, 2005), scholars using naturalistic data have to find creative ways to work with what is there. This can be provocative for scholars and may lead to surprising findings.

In our study, we identified the company archive of LG as an appropriate main research site. The company archive, preserved in a public repository, contains empirical materials from 1896 to 1996 and its volume amounts up to 260 shelf yards. ${ }^{2}$ In the Political Firm Case research project, the preliminary strategy was to identify materials that provide insights into the firms' engagement practices with the wider society. In the very beginning of the fieldwork in the archive, we started the collection of the material by looking through the consulting catalogues 
and thematic files of the archive in order to get an impression of the kind of records that had been preserved. It was in one of these files that we noticed an interesting episode in the history of the company (i.e., LG's response to the Hungarian uprising) that later became the starting point for this theoretically motivated case study. From there, we then started to systematically collect any material related to LG's approach to Eastern trade in the company archive, for instance, minutes of the $\mathrm{BoD}$, correspondence letters, transcripts of speeches, internal reports, newspaper articles and so on. It is important to note that we never considered these empirical materials to be a clear window into the company's past (Decker, 2013), but saw them as intentionally constructed, value-laden and ambiguous.

Source criticism. In order to make use of historical sources that are of an incomplete and ambiguous nature, RHCS relies on the methodological tool of source criticism (Lipartito, 2014; Kipping et al., 2014). Source criticism is a reflexive device for establishing arguments and for identifying the extent to which a historical source can be used to address a research question (Kipping et al., 2014). In dealing with data in such a reflexive way, it is important to understand that historians read "sources 'against the grain' (Clark, 2004: 126; Evans, 1997:143; Gunn, 2006: 169), inferring a meaning beyond, or even opposed to, what the sources were intended to mean" (Rowlinson et al., 2014, p. 256). With this operation, historians transform “traces [i.e., social documents] from the past into sources [i.e., research data]" (Hansen, 2013, p. 695), meaning that historical sources are made the very moment scholars use materials from the past to answer their research questions

In our research endeavor, our main task was not to understand what actually happened but to understand how the informants created their reality in context and over time. Through source criticism, we concluded that part of the material—e.g., the BoD minutes—can account for analyzing the different organizational actors' interpretations of the public issue, i.e., meaning constructions or rationales used in the company. In documents referring to the particular 
episode, we were able to identify struggling narratives that were put forward to explain LG's role during the crisis. Some managers argued quite simply that a business' business is business. In contrast, other managers introduced the line of argument that a firm should be obliged to follow broader societal goals, defending the apparent "superior" values of the West against an “aggressive” Eastern bloc. In Gadamer's (2013) terms, the material reveals the different horizons of the actors. These texts were then complemented with sources that allowed us to contextualize the expressions of the actors within the overall hermeneutic situation. For instance, we collected pamphlets of pro- and anti-Eastern trade advocates from the relevant period. This contextualization reflects our approach to understand an empirical instance within pre-given but dialectically improving understandings. This brings us to the last key characteristic.

\section{Key Characteristic No. 3: Theory Elaboration from History}

The last and crucial key characteristic of historical analysis is the ability to look at developments and events from a temporal distance. We essentially argue, in line with Gadamer (2013), that an empirical context in temporal distance helps to filter out the scholars' "false" prejudices, which might be shaped by the taken-for-granted assumptions of the literature. In what follows, we clarify the reflexive space of history that enables understanding according to Gadamer.

Interpretive approach to challenge prejudices. RHCS adopts an interpretive approach to case research that is in sharp contrast to the two prime templates, which prejudge "the" case as an instance of the theory the scholars are inductively developing (Eisenhardt et al., 2016). Interpretive scholars, instead, as explicated by Alvesson and Kärreman (2011), regard empirical case research as a practice "to enhance [scholars'] ability to challenge, rethink and illustrate theory" (Alvesson \& Kärreman, 2011, p. 4). In Alvesson and Kärreman’s (2007) language, scholars have to create a "breakdown" in understanding, in which prior theoretical propositions 
fail to make sense of an empirical instance. To provoke such breakdowns, Alvesson and Kärreman (2007) direct scholars to look at rather striking and idiosyncratic empirical examples and to mobilize a broad "repertoire of lenses" in order to critically open up alternative ways of framing the empirical instance.

RHCS, however, has an additional leverage effect. Gadamer (2013) points towards the significance of temporal distance, separating the researchers' and the researched context, which may facilitate the creation of such breakdowns. As argued above, researchers bring to the act of understanding not only their theoretical expectations but also their whole situatedness within a historico-cultural context. In this respect, temporal distance "is not something that must be overcome" (Gadamer, 2013, p. 308). Rather, it is a productive condition enabling novel understandings, since temporal distance makes the taken-for-grantedness of prejudices, embedded in our historical time and place, intelligible (Gadamer, 2013). In our research, studying the early Cold War period was provoking because it gave us access to pre-theoretical empirical material. By going back in time, we had the opportunity to study phenomena not yet "distorted" by contemporary management discourses, such as CSR speech, trained in management education (Laamanen, Lamberg, \& Vaara, 2016). Temporal distance, thus, provides a reflexive space in which present-day prejudices can be filtered out (Gadamer, 2013).

The hermeneutic circle. To facilitate an understanding of empirical instances, the socalled "hermeneutic circle" is the key concept to describe the research practice (Gadamer, 2013). It describes a practice in which understanding can only be achieved through considering the "whole" and the "parts", whereas "the part [can only be] understood from the whole and the whole from the inner harmony of its part" (Palmer, 1969, p. 77 cited in Prasad, 2002, p. 17). In other words, scholars might start their research with a preunderstanding, the "whole", in order to engage in a dialectic dialogue with the empirical instance, the "part". A productive dialogue, then, leads to a novel understanding of the "whole". This research practice is in sharp 
contrast to inductive approaches, in which theory seems to emerge computationally from the data by way of extensive coding. Hermeneutic understanding rather emphasizes the cognitive aspects of understanding where scholars are seen as active, historically embedded, reasoners.

In our research endeavor, we started with a theoretical expectation proposed by Bundy and colleagues (2013) and some preunderstandings about the historical context in which the events unfolded (e.g., secondary literature by other historians, such as Tanner, 1999). It is important to note here that the "context" is not a given but needs to be defined by the scholars (Prasad, 2002). In this explorative attempt, scholars can "zoom in" to decipher the empirical instance, but also "zoom out" to see the antecedents and consequences over a long period of time (Wadhwani \& Bucheli, 2014). In our empirical case, we took the large-scale political environment of the Cold War period into account, as well as the specific cultural, political and economic context of Switzerland, but also proceeding events on the organizational level, such as the confiscation of LG property by communist Eastern countries that had occurred years before the empirical instance (see Figure 1).

Abductive reasoning. The scientific mode of reasoning that describes the practice of the application of the hermeneutic circle is abduction, that is, inference to the best explanation (Mantere \& Ketokivi, 2013). The general logic of abduction is to turn surprising facts into matters of course: When scholars find a conflict between the empirical instance and the existing theoretical postulation, they attempt to integrate the anomalies of the empirical instance into the initial explanatory scheme through a search process for the new best explanation that covers the anomalies (id.). In our study, the empirical instance - the termination of customer relations to Eastern countries - could not be explained by the prior theoretical propositions by Bundy and colleagues (2013). In particular, our analysis revealed that LG's decision to terminate customer relations with eastern European countries draws on narratives from the broader sociocultural context rather than on prevailing norms and values of the focal organization. Through 
contextualizing, we came to know that conservative and anti-communist pressure groups coined the political narrative about the political role of trade long before, aiming at adjusting business interests with the defense of the "free" Western world. These findings suggested that the external environment generates and justifies the firm-specific sensemaking processes; a finding that created a breakdown because prior propositions by Bundy and colleagues (2013) did not take this into account. This breakdown offered us an opportunity to examine the role of the social and political environment on the mechanisms that drives a firm's actions regarding stakeholder issues more comprehensively (see Stutz, 2016).

To sum up, RHCS has guided us towards critiquing and reflexively elaborating on existing theory by looking at empirical instances in context and over time. In explicating the three key characteristics of RHCS we brought forth reflexive ideas concerning theories, empirical material and research procedures that allow pursuit of the research agenda of the grander aims while simultaneously contributing to a theoretical debate.

\section{Discussion}

We set out to demonstrate the potential of historical research for B\&S scholarship. With a particular focus on the normative challenges of qualitative research, we have presented a reflexive use of history as an alternative to two well-known inductive research templates that are limited in important ways in confronting and dealing with these challenges. This section elaborates on RHCS's potential for addressing issues and debates associated with the B\&S agenda and then discuss possible limitations in its applicability in B\&S research.

\section{A Research Agenda for RHCS Research}

In the following we explicate three particular strengths of the proposed research strategy that would benefit B\&S research domains. RHCS could be applied to almost any theoretical debate 
in the B\&S field. However, we focus our application on corporate social responsibility (CSR) and stakeholder theory literature given their prominence in B\&S research (Crane, Henriques, Husted, \& Matten, 2016).

Challenging assumptions embedded in CSR research. We have argued that RHCS has reflexive concerns about theories and aims at challenging and refining them. Our argument suggests that empirical instances in the past might stimulate us to question our contemporary concepts, because the separation between the scholars' contemporary context and the research context might provoke scholars to be surprised by the data and encourage them to engage in new ways of thinking about a phenomenon.

As a promising avenue for this kind of research, we suggest that scholars might begin to investigate more profoundly the ground assumptions in CSR research, for instance, in the literature about the political role of business (Matten \& Crane, 2005; Scherer \& Palazzo, 2007; Scherer, Palazzo, \& Matten, 2014; Schrempf-Stirling, Palazzo, \& Phillips, 2016). To examine the assumptions embedded in this literature, the recent historical study by Djelic and Etchanchu (2015) can serve as an intriguing example for further historical research, although it is not based on in-depth analysis of archival records but on archival work of other historians. Similar to Gadamer, they regard theoretical concepts as both historically and ideologically embedded and analyze political CSR as "a particular and contextual form of business-society interactions that reflects and reveals certain institutional and cultural conditions, particular relations of power and a given ideological and value grounding" (id., p. 4). To uncover the taken-for-grantedness of political CSR (as articulated by Matten and Crane, 2005), Djelic and Etchanchu (2015) confront the set of presuppositions of political CSR with alternative historical patterns of businesssociety interactions. Amongst other findings, their study reveals that private actors have always played a political role and it shows how the nature, extent and impact of that political role 
changed in conjunction with the dominant ideologies underpinning the particular business-society interactions.

In accordance with this study, we suggest that RHCS provides the methodological guidelines of how in-depth historical research can challenge the assumptions in contemporary literature. To transform what is commonly seen as unquestioned truths in our concepts, scholars might also be inspired by the heuristic categories of assumptions provided by Alvesson and Sandberg (2011). For instance, political CSR might hold an ideological assumption about the role of the nation state. We hope that historical research can further contribute to this influential stream of CSR research by challenging, refining and elaborating on its core concepts.

Approaching social context in CSR theorizing. We have presented RHCS as a contextsensitive methodology. To unleash this potential, a possible avenue of investigation involves applying RHCS to the branch of CSR research that examines the role of social context in CSR practices (Aguilera, Rupp, Williams, \& Ganapathi, 2007; Matten \& Moon, 2008). Athanasopoulou and Selsky (2015, p. 354) have recently called for more "in-depth and context-intensive research", proposing that CSR researchers should incorporate multiple levels of social context more deliberately and study their interrelations. While they do not outline how scholars could approach this research agenda methodologically, their call can be appropriately answered by applying RHCS as a context-sensitive methodology.

RHCS is context-sensitive in multiple ways: Scholars might start their empirical research by engaging with different theoretical perspectives that provide scholars with unlikely initial illuminations, insights and preunderstandings to study different facets of social worlds. Scholars guided by RHCS could combine, as Athanasopoulou and Selsky (2015) have suggested, institutional, cultural and cognitive perspectives, each addressing distinct context levels. Scholars interested in exploring the conditions in which CSR initiatives emerge may then find in the hermeneutic circle an appropriate analytical tool to employ an analysis on multiple 
levels of context in a single study. In hermeneutic analysis, scholars increase their understanding in a spiral movement, in which they contextualize the empirical instance by gradually moving from a low level of context towards higher levels. Historical research uses heterogeneous types of naturalistic data that help to understand issues on micro, meso and macro levels.

Furthermore, RHCS directs scholars to reflexive concerns with "context", recognizing competing contexts. McLaren and Durepos (2015) lamented that context is one of the most undertheorized terms across all research paradigms and rarely becomes a part of what is studied. Instead of treating context as a "fixed or pre-existing container" into which researchers can place phenomena, McLaren and Durepos (2015) propose to take contexts as socially constructed phenomena seriously. To account for the complexity of the lived world, they make a case to work with a variety of contexts rather than different levels of context. In this respect, researchers can find conceptual guidance in Gadamer's thinking, the major philosophical-conceptual underpinning of RHCS. According to Gadamer, social groups construct their very own hermeneutic horizons, which shape distinct understandings, even though they are situated in the same overall hermeneutic situation. We suggest that RHCS research may contribute to a more critical view of context and expand and enrich our understanding of CSR behavior in multiple interrelated levels of social context.

Converging "grander aims" and theorizing efforts. We have primarily argued that the "grander aims" of B\&S scholarship are an obstacle for the application of the two well-known prime templates discussed above: The templates are committed to the scientific realist view for studying organizations and make scholars conceal their own norms and beliefs. RHCS, in contrast, allows scholars to deliberately acknowledge their agenda. In this regard, we propose that RHCS research can particularly add to approaches within stakeholder theory (Freeman et al., 2010; Post, Preston, \& Sachs, 2002). Stakeholder theory presents itself more as a worldview with a "set of unifying ideas" or a "genre" of management research (Freeman et al., 2010, p. 
64) than a scientific theory. Indeed, its value-laden core assumptions are carefully conceptualized out of the "theoretical ether" (Gioia, 1999, p. 230) to inform business decision making on normative grounds. Inspired by the pragmatist philosopher Richard Rorty, the research agenda laid out by Freeman and colleagues aims to generate "insights that help us to lead better lives" (Freeman et al., 2010, p. 75). Any generated knowledge is, thus, assessed according to whether it is useful for the advancement of morally legitimate business practices.

RHCS is a reflexive methodology that can help ground stakeholder theory in practical reality. To be specific, RHCS acknowledges that not all textual interpretations are equally valid. In the operation of the hermeneutic circle, scholars can reflexively filter out illegitimate prejudices by going beyond the surface of the empirical instances studied (Prasad, 2002). In this regard, Tadajewski's (2015) recent historical study of the Rotary Club is a promising starting point. Examining the key ideas about social responsibilities of business promoted by this organization in the early $20^{\text {th }}$ century, he uses the historical case to underscore the lack of validity of the so-called separation thesis, i.e., that business and moral decision-making should and can be clearly differentiated. Indeed, values and facts are completely entangled (Putnam, 2002). We share Tadajewski's conclusion (2015, p. 23) that "an extensive program of research that details the close connections between business practice and ethical responsibility can provide the intellectual tool to start to revise negative public perceptions [i.e., the view that has permeated popular culture, with business practice frequently depicted as 'amoral']'. In RHCS, theorizing efforts and grander aims converge to "change the underlying narrative about business" (Freeman, et al., 2010, p. 63).

\section{Limitations}

We recognize that there are many potential obstacles for implementing the proposed methodology in B\&S scholarship. First of all, Gadamer understood hermeneutics as a human practice, 
not reducible to the application of formal methods (Miller, 2005). The question arises as to whether the proposed research strategy is doomed to failure. In the face of his radical conception of understanding, we recognize that he uses hermeneutics as a protection against the "abuse of method" (Gadamer, 1992, p. 70). Gadamer, however, does not come out in opposition to "methodologicalness" of science in general (id.). At the very end of his main opus, he clarifies that "[t]he fact that ... the knower's own being comes into play certainly shows the limits of method, but not of science. Rather, what the tool of method does not achieve must — and really can - be achieved by a discipline of questioning and inquiry, a discipline that guarantees truth" (Gadamer, 2013, p. 506). In this regard, we do not wish to portray RHCS as a set of formalized procedures that guarantees a successful research outcome. On the contrary, RHCS claims only to entail methodological guidelines derived from hermeneutics. In particular, we build on Gadamer's insights that point towards the potential of history for enhancing reflexivity for the generation of novel knowledge.

Second, the proposed hermeneutic approach to history shares ground assumptions with the interpretive tradition to study organization and appears to be in competition with the realist view of studying organizations, which is the dominant style of research in MOS. Realist scholars might question its generalizability and the unbiasedness of its findings. Ketokivi and Mantere (2010), however, have argued that this kind of critique is of a political nature and is not adequate for a scientific debate between authors and the audience. Rather, the audience should accept the research strategy chosen by the authors and move from exogenous critique to an endogenous dialogue in order to critically evaluate the authors' argument within the research tradition. In particular, interpretive research faces the challenge of subjectivism (Ketokivi \& Mantere, 2010). In this regard, authors have to persuade their audience of the credibility of the judgements, assumptions and explanations made (Mantere \& Ketokivi, 2013). 
Thirdly, alternative approaches to history might be more appropriate in order to pursue the research questions that $\mathrm{B} \& \mathrm{~S}$ scholars might wish to explore. To be specific, our proposed methodology is built on the conceptualizing alternative to history (Maclean et al., 2016), modified for the purpose of dealing with the normative challenges. Other variants of historical approaches serve different epistemic aims and are underpinned by philosophical assumptions different to those of RHCS (see also Rowlinson et al., 2014, and Vaara \& Lamberg, 2016). For instance, scholars interested in understanding the origins of CSR and its development in time are best served by the narrating methodological alternative to historical research, as conceptualized by Maclean and colleagues (2016).

Fourthly and finally, historical research has some general limitations that should be considered when employing a historical lens. To begin with, historical research approaches are very time-consuming and difficult to plan. The research strategy has to be very flexible in order to work with what is there. It further faces the problem of survivor bias: i.e., sources are lost, widely dispersed and hard to identify (Decker, 2013). Even the identification of a suitable research site might be difficult, for instance, due to the preservation habits of companies, the arbitrarily granted access to company archives or the time seal that may prevent the use of material before a certain time has elapsed (Lipartito, 2014). And finally, doing historical research requires experienced-based knowledge up to a certain extent. In this vein, reflexive historical case research might be best employed in an interdisciplinary collaboration between $B \& S$ scholars and historians.

\section{Conclusion}

At the beginning of this article, we have asked why and how B\&S scholars should consider a historical lens and research strategies informed by historiography. Based on insights from philosophical hermeneutics and recent work on scientific reasoning in MOS, we have identified 
the potential pitfalls of the inductive prime templates and presented a hermeneutic approach to history as a way to address them. We have argued that both the Eisenhardt and the Gioia template emphasize the computational manner of doing research, when in our opinion interesting and novel findings are actually constructed by cognitive minds. By stressing researcher invariant activities, research presented in the realist paradigm can be criticized as to whether and to which extent the findings are biased by the normative agenda (Rost \& Ehrmann, 2015). Moreover, research that does not acknowledge and reflect the researchers' norms is at risk of (inadvertently) crafting political narratives. Finally, by considering the normative challenge to deal productively with research subjects' norms, we have argued that both templates offer scholars methodologically incomplete guidelines to confront their preunderstandings with the research context in order to produce novel knowledge.

The principal argument — why to do history? — has been that historical research has the potential to address those normative challenges. This was demonstrated by explicating three key characteristics. To be specific, RHCS acknowledges that scholars are historically situated active reasoners and it has reflexive concerns about the nature of theory and empirical material. RHCS then uses naturalistic "data" from the periods under study and further has the analytical leverage of temporal distance: Empirical context in the temporal past might provoke scholars' contemporary preunderstandings and stimulate them to move towards new understandings. In order to give practical guidance- how to do history? - , we have illustrated and developed those characteristics with a case example. Building on the conceptualizing approach to history, we have presented a theory elaboration approach to history, synthesizing ideas of interpretive research, philosophical hermeneutics and historiography.

We suggest that our argument has at least three implications for B\&S scholarship. First, we have clarified the normative challenges and identified a set of potential pitfalls for qualitative research. Although the temporal angle of historical research is an inimitable comparative 
advantage, the synthesized methodological insights can inform scholars to adapt a more reflexive research habitus in order to partly confront these challenges. Future research is invited to extend the discussion about the normative challenges of qualitative research and broaden the legitimate styles of doing research within $\mathrm{B} \& \mathrm{~S}$.

Second, we elaborated on the conceptualizing approach to history and refined it as a reflexive theory elaboration approach. Our article thus also contributes to the very recent debate about the future direction of historical organization studies (Kipping \& Üsdiken, 2014; Maclean et al., 2016; Rowlinson et al., 2014; Vaara \& Lamberg, 2016, Wadhwani \& Bucheli, 2014) and business history (Decker, Kipping, \& Wadhwani, 2015). Thirdly and finally, we have introduced a particular type of history to B\&S scholarship in order to extend the work already done. To tap the potential of "history", we have envisioned a research program for scholars interested in employing historical research in the B\&S field. We hope that this article will encourage historical research that contributes to issues and debates within the B\&S agenda.

\section{Acknowledgements}

This article has benefited greatly from the detailed and constructive comments of the anonymous reviewers and the responsible editor Bryan Husted on previous drafts, which helped us to clarify our thoughts and arguments. We are also indebted to Juha-Antti Lamberg, Vanessa McSorley, Heli Valtonen and the participants of the research seminars at the University of Jyväskylä (Finland) and at the HWZ University of Applied Sciences in Business Administration in Zurich (Switzerland) for their significant support in improving and finalizing this article. 


\section{References}

Aguilera, R. V., Rupp, D. E., Williams, C. A., \& Ganapathi, J. (2007). Putting the S back in corporate social responsibility: A multilevel theory of social change in organizations. Academy of Management Review, 32(3), 836-863.

Alvesson, M., \& Gabriel, Y. (2013). Beyond formulaic research: In praise of greater diversity in organizatinoal research and publications. Academy of Management Learning \& Education, 12(2), 245-263.

Alvesson, M., \& Kärreman, D. (2007). Constructing mystery: Empirical matters in theory development. Academy of Management Review, 32(4), 1265-1281.

Alvesson, M., \& Kärreman, D. (2011). Qualitative research and theory development: Mystery as method. Thousand Oaks, CA: Sage Publications.

Alvesson, M., \& Sandberg, J. (2011). Generating research results through problematization. Academy of Management Review, 36(2), 247-271.

Athanasopoulou, A., \& Selsky, J. W. (2015). The social context of corporate social responsibility: Enriching research with multiple perspectives and multiple levels. Business \& Society, 54(3), 322-364.

Barrett, F. J., Powley, E. H., \& Pearce, B. (2011). Hermeneutic philosophy and organizational theory. In H. Tsoukas \& R. Chia (Eds.), Philosophy and organization theory (pp. 181213). London, England: Emerald.

Boje, D. M. (1995). Stories of the storytelling organization: A postmodern analysis of Disney as "Tamara-land.” Academy of Management Journal, 38(4), 997-1035.

Bundy, J., Shropshire, C., \& Buchholtz, A. K. (2013). Strategic cognition and issue salience: Toward an explanation of firm responsiveness to stakeholder concerns. Academy of Management Review, 38(3), 352-376.

Butterfield, K. D., Reed, R., \& Lemak, D. J. (2004). An inductive model of collaboration from 
the stakeholder's perspective. Business \& Society, 43(2), 162-195.

Carroll, A. B. (1999). Corporate social responsibility: Evolution of a definitional construct. Business \& Society, 38(3), 268-295.

Carroll, A. B., Lipartito, K., Post, J. E., \& Werhane, P. H. (2012). Corporate responsibility: The American experience. New York, NY: Cambridge University Press.

Cook, R. G., \& Barry, D. (1995). Shaping the external environment: A study of small firms' attempts to influence public policy. Business \& Society, 34(3), 317-344.

Corley, K. G., \& Gioia, D. A. (2004). Identity ambiguity and change in the wake of a corporate spin-off. Administrative Science Quarterly, 49(2), 173-208.

Crane, A., Henriques, I., Husted, B. W., \& Matten, D. (2016). What constitutes a theoretical contribution in the Business and Society field? Business \& Society, 55(6), 783-791.

Decker, S. (2013). The silence of the archives: Business history, post-colonialism and archival ethnography. Management and Organizational History, 8(2), 155-173.

Decker, S., Kipping, M., \& Wadhwani, R. (2015). New business histories! Plurality in business history research methods. Business History, 57(1), 30-40.

Djelic, M., \& Etchanchu, H. (2015). Contextualizing corporate political responsibilities: Neoliberal CSR in historical perspective. Journal of Business Ethics. http://doi.org/10.1007/s10551-015-2879-7

Donaldson, T., \& Preston, L. E. (1995). The stakeholder theory of the corporation: Concepts, evidence, and implications. Academy of Management Review, 20(1), 65-91.

Dyer, W. G., \& Wilkins, A. L. (1991). Better stories, not better constructs, to generate better theory: A rejoinder to Eisenhardt. Academy of Management Review, 16(3), 613-619.

Eisenhardt, K. M. (1989). Building theories from case study research. Academy of Management Review, 14(4), 532-550.

Eisenhardt, K. M., Graebner, M. E., \& Sonensheim, S. (2016). Grand challenges and inductive 
methods: Rigor without rigor mortis. Academy of Management Journal, 59(4), 11131123.

Freeman, R. E., Harrison, J. S., Wicks, A. C., Parmar, B. L., \& de Colle, S. (2010). Stakeholder theory: The state of the art. Cambridge, England: Cambridge University Press.

Gadamer, H.-G. (1992). Interview: Writing and the living voice. In D. Misgeld \& G. Nicholson (Eds.), Hans-Georg Gadamer on Education, Poetry and History (pp. 63-71). New York: State University of New York Press.

Gadamer, H.-G. (2013). Truth and method (rev. 2nd ed.). London, England: Bloomsbury Academic.

Gioia, D. A. (1999). Practicability, paradigms, and problems in stakeholder theorizing. Academy of Management Review, 24(2), 228-232.

Gioia, D. A., Corley, K. G., \& Hamilton, A. L. (2013). Seeking qualitative rigor in inductive research: Notes on the Gioia methodology. Organizational Research Methods, 16(1), 1531.

Glaser, B., \& Strauss, A. (1967). The discovery of grounded theory: Strategies for qualitative research. Hawthorne, NY: Aldine de Gruyter.

Ghoshal, S. (2005). Bad management theories are destroying good management practices. Academy of Management Learning \& Education, 4(1), 75-91.

Hansen, P. H. (2012). Business history: A cultural and narrative approach. Business History Review, 86(4), 693-717.

Hassard, J., \& Cox, J. W. (2013). Can sociological paradigms still inform organizational analysis? A paradigm model for post-paradigm times. Organization Studies, 34(11), $1701-1728$.

Heracleous, L., \& Barrett, M. (2001). Organizational change as discourse: Communicative actions and deep structure in the context of information technology implementation. 
Academy of Management Journal, 44(4), 755-778.

Heugens, P. P. M. A. R., van den Bosch, F. A. J., \& van Riel, C. B. M. (2002). Stakeholder integration: Building mutually enforcing relationships. Business \& Society, 41(1), 36-60.

Husted, B. W. (2015). Corporate social responsibility practice from 1800-1914: Past initiatives and current debates. Business Ethics Quarterly, 25(1), 125-141.

Ketokivi, M., \& Choi, T. (2014). Renaissance of case research as a scientific method. Journal of Operations Management, 32(5), 232-240.

Ketokivi, M., \& Mantere, S. (2010). Two strategies for inductive reasoning in organizational research. Academy of Management Review, 35(2), 315-333.

Kieser, A. (1994). Why organization theory needs historical analyses: And how this should be performed. Organization Science, 5(4), 608-620.

Kipping, M., \& Üsdiken, B. (2014). History in organization and management theory: More than meets the eye. The Academy of Management Annals, 8(1), 1-83.

Kipping, M., Wadhwani, R. D., \& Bucheli, M. (2014). Analyzing and interpreting historical sources: A basic methodology. In M. Bucheli \& R. D. Wadhwani (Eds.), Organizations in time: History, theory, methods (pp. 305-325). Oxford, England: Oxford University Press.

Laamanen, T., Lamberg, J.-A., \& Vaara, E. (2016). Explanations of success and failure in management learning: What can we learn from Nokia's rise and fall? Academy of Management Learning \& Education, 15(1), 2-25.

Lamberg, J., Skippari, M., Eloranta, J., \& Mäkinen, S. (2004). The evolution of corporate political action: A framework for processual analysis. Business \& Society, 43(4), 335365.

Langley, A., \& Abdallah, C. (2011). Templates and turns in qualitative studies of strategy and management. In D. Ketchen \& D. Bergh (Eds.), Building methodological bridges (pp. 
137-159). Bingley, England: Emerald.

Laplume, A. O., Sonpar, K., \& Litz, R. A. (2008). Stakeholder theory: Reviewing a theory that moves us. Journal of Management, 34(6), 1152-1189.

Lipartito, K. (2014). Historical source and data. In M. Bucheli \& R. D. Wadhwani (Eds.), Organizations in time: History, theory, methods (pp. 284-304). Oxford, England: Oxford University Press.

Maclean, M., Harvey, C., \& Clegg, S. R. (2016). Conceptualizing historical organization studies. Academy of Management Review, 41(4), 609-632.

Mantere, S., \& Ketokivi, M. (2013). Reasoning in organization science. Academy of Management Review, 38(1), 70-89.

Marens, R. (2013). What comes around: The early 20th century American roots of legitimating corporate social responsibility. Organization, 20(3), 454-476.

Matten, D., \& Crane, A. (2005). Corporate citizenship: Toward an extended theoretical conceptualization. Academy of Management Review, 30(1), 166-179.

Matten, D., \& Moon, J. (2008). "Implicit" and "explicit" CSR: A conceptual framework for a comparative understanding of corporate social responsibility. Academy of Management Review, 33(2), 404-424.

McLaren, P. G., \& Durepos, G. (2015). Theorizing context in management and organization studies. In Academy of Management Proceedings (pp. 1-28). http://doi.org/10.5465/AMBPP.2015.13431abstract

Miller, K. D. (2005). The problem of method and the practice of management research. In J. Ketchen, David J. \& D. D. Bergh (Eds.), Research methodology in strategy and management (pp. 143-177). Amsterdam, The Netherlands: Elsevier.

Mitchell, R. K., Agle, B. R., \& Wood, D. J. (1997). Toward a theory of stakeholder identification and salience: Defining the principle of who and what really counts. Academy 
of Management Review, 22(4), 853-886.

Näsi, J., Näsi, S., Phillips, N., \& Zyglidopoulos, S. (1997). The evolution of corporate social responsiveness: An exploratory study of Finnish and Canadian forestry companies. Business \& Society, 36(3), 296-321.

Phillips, N., \& Brown, J. L. (1993). Analyzing communication in and around organizations: A critical hermeneutic approach. Academy of Management Journal, 36(6), 1547-1576.

Post, J. E., Preston, L. E., \& Sachs, S. (2002). Redefining the corporation: Stakeholder management and organizational wealth. Stanford, CA: Stanford University Press.

Potter, J., \& Hepburn, A. (2005). Qualitative interviews in psychology: Problems and possibilities. Qualitative Research in Psychology, 2(4), 281-307.

Prasad, A. (2002). The contest over meaning: Hermeneutics as an interpretive methodology for understanding texts. Organizational Research Methods, 5(1), 12-33.

Putnam, H. (2002). The collapse of the fact/value dichotomy and other essays. Cambridge, MA: Harvard University Press.

Rost, K., \& Ehrmann, T. (2015). Reporting biases in empirical management research: The example of win-win corporate social responsibility. Business \& Society. http://doi.org/10.1177/0007650315572858

Rowlinson, M., Hassard, J., \& Decker, S. (2014). Research strategies for organizational history: A dialogue between historical theory and organization theory. Academy of Management Review, 39(3), 250-274.

Sachs, S., \& Rühli, E. (2011). Stakeholder matters: A new paradigm for strategy in society. Cambridge, England: Cambridge University Press.

Scherer, A. G., \& Palazzo, G. (2007). Toward a political conception of corporate responsibility: Business and society seen from a Habermasian perspective. Academy of Management Review, 32(4), 1096-1120. 
Scherer, A. G., Palazzo, G., \& Matten, D. (2014). The business firm as a political actor: A new theory of the firm for a globalized world. Business \& Society, 48(4), 577-580.

Schlesinger, A. M. (1999). The cycles of American politics. In The cycles of American history (pp. 23-48). New York, NY: Mariner Books.

Schrempf-Stirling, J., Palazzo, G., \& Phillips, R. A. (2016). Historic corporate social responsibility. Academy of Management Review, 41(4), 700-719.

Scranton, P. (2014). Business history and anthropology. Journal of Business Anthropology, $3(1), 65-71$.

Stutz, C. (2016). Elaborating the strategic cognition view of issue salience: A historical case study on the role of the socio-political context. In R. E. Freeman, J. Kujala, \& S. Sachs (Eds.), Stakeholder engagement: Clinical research cases. Dordrecht, The Netherlands: Springer. Manuscript submitted for publication.

Tadajewski, M. (2015). The Rotary Club and the promotion of the social responsibilities of business in the early 20th century. Business \& Society. http://doi.org/10.1177/0007650315609048

Tanner, J. (1999). Switzerland and the Cold War: A neutral country between the "American way of life" and "geistige Landesverteidigung." In J. Charnley \& M. Pender (Eds.), Switzerland and war (pp. 113-128). Bern, Switzerland: Peter Lang.

Vaara, E., \& Lamberg, J.-A. (2016). Taking historical embeddedness seriously: Three historical approaches to advance strategy process and practice research. Academy of Management Review, 41(4), 633-657.

Wadhwani, R. D., \& Bucheli, M. (2014). The future of the past in management and organization studies. In M. Bucheli \& R. D. Wadhwani (Eds.), Organizations in time: History, theory, methods (pp. 3-32). Oxford, England: Oxford University Press.

Walsh, J. P., Weber, K., \& Margolis, J. D. (2003). Social issues and management: Our lost 
cause found. Journal of Management, 29(6), 859-881.

Weatherbee, T. G., McLaren, P. G., \& Mills, A. (2015). Introduction: The historic turn in management and organizational studies: A companion reading. In P. G. McLaren, A. J. Mills, \& T. G. Weatherbee (Eds.), The Routledge companion to management and organizational history (pp. 3-10). Oxford, England: Routledge.

Wicks, A. C., \& Freeman, R. E. (1998). Organization studies and the new pragmatism: Positivism, anti-positivism, and the search for ethics. Organization Science, 9(2), 123140.

Wry, T. E. (2009). Does business and society scholarship matter to society? Pursuing a normative agenda with critical realism and neoinstitutional theory. Journal of Business Ethics, 89(2), 151-171.

Zald, M. N. (1993). Organization studies as a scientific and humanistic enterprise: Toward a reconceptualization of the foundations of the field. Organization Science, 4(4), 513-528. 


\section{Appendix}

Method to identify qualitative B\&S literature. We searched the Business \& Society journal archive for use of terms such as "qualitative study", "qualitative case study", "qualitative research", "qualitative method", "qualitative approach", etc. (record date: 11/2015). As some articles appeared as search results for several search terms, we then merged the results producing a list of 108 single articles. We then screened the method section of each article to sort out quantitative and conceptual studies (69 articles remaining). Furthermore, we excluded articles that were not fully developed studies in terms of text genres (such as dissertation abstracts), so we could restrict our sample of qualitative studies to 52 articles. We finally categorized the qualitative articles according to their affinity with research traditions (inductive research; interpretive research; theory-testing research according to Mantere and Ketokivi, 2013) and their underlying paradigmatic assumptions in theorizing (positivist or structural; constructionist or anti-structural, postmodern or post-structural positions according to Hassard and Cox, 2013). Our sample confirms the significance of the positivist Eisenhardt and constructionist Gioia template in providing guiding principles, both belonging to the inductive research tradition (cf. Mantere \& Ketokivi, 2013; Eisenhardt et al., 2016).

Based on the sample of qualitative papers that we identified, we chose to read the most cited articles, using both Thomson Reuters' Web of Knowledge and Google Scholar to indicate the scholarly attention each article received. From this selection, we chose examples for the article that were particularly compelling. However, we recognize the limits of the partially idiosyncratic set of articles, but evaluating a more extensive sample would go beyond the purpose of illustrating the pitfalls. 
Key characteristics of Landis \& Gyr and Switzerland during study period.

Insert table 2 about here 


\section{Tables and Figures}

\section{Table 1: Characteristics of Case(s) Study Approaches in Comparison}

\begin{tabular}{|c|c|c|c|}
\hline & Eisenhardt case(s) study & Gioia case study & Reflexive hist. case study \\
\hline Purpose & - Generating novel theory & $\begin{array}{l}\text { - Generating novel concep- } \\
\text { tualizations or models }\end{array}$ & $\begin{array}{l}\text { - Reflexive elaboration on } \\
\text { existing theories }\end{array}$ \\
\hline $\begin{array}{l}\text { Mode of enquiry } \\
\text { - Main concerns of } \\
\text { enquiry }\end{array}$ & $\begin{array}{l}\text { - Discovering facts and } \\
\text { identify cause and effect }\end{array}$ & $\begin{array}{l}\text { - Understanding research } \\
\text { subjects' understanding of a } \\
\text { phenomenon }\end{array}$ & $\begin{array}{l}\text { - Understanding research } \\
\text { subjects' understanding of a } \\
\text { phenomenon in context and } \\
\text { over time }\end{array}$ \\
\hline $\begin{array}{l}\text { - Onto-epistemolog- } \\
\text { ical assumptions }\end{array}$ & - Realist position & $\begin{array}{l}\text { - Moderate constructionist } \\
\text { position; but also bound to } \\
\text { the scientific realist view }\end{array}$ & $\begin{array}{l}\text { - Moderate constructionist } \\
\text { position }\end{array}$ \\
\hline $\begin{array}{l}\text { - Nature of re- } \\
\text { searcher }\end{array}$ & - Rational researcher & $\begin{array}{l}\text { - Researcher as a "knowl- } \\
\text { edgeable agent"; tends to } \\
\text { emphasize researcher invar- } \\
\text { iant research practices }\end{array}$ & $\begin{array}{l}\text { - Researcher as an active, } \\
\text { historically embedded rea- } \\
\text { soner }\end{array}$ \\
\hline - Nature of data & $\begin{array}{l}\text { - Research subjects' state- } \\
\text { ments are rendered as ob- } \\
\text { jective facts }\end{array}$ & $\begin{array}{l}\text { - Research subjects as } \\
\text { "knowledgeable agents" }\end{array}$ & $\begin{array}{l}\text { - Incomplete and ambigu- } \\
\text { ous informants' accounts; } \\
\text { using heterogeneous natu- } \\
\text { ralistic empirical material }\end{array}$ \\
\hline $\begin{array}{l}\text { - Main style of rea- } \\
\text { soning }\end{array}$ & $\begin{array}{l}\text { - Mainly inductive reason- } \\
\text { ing }\end{array}$ & $\begin{array}{l}\text { - Mainly inductive reason- } \\
\text { ing }\end{array}$ & $\begin{array}{l}\text { - Mainly abductive reason- } \\
\text { ing }\end{array}$ \\
\hline $\begin{array}{l}\text { - Main method of } \\
\text { analysis }\end{array}$ & $\begin{array}{l}\text { - Systematically comparing } \\
\text { variation of features of the } \\
\text { cases (method of elimina- } \\
\text { tive induction) }\end{array}$ & $\begin{array}{l}\text { - Adopting a version of } \\
\text { grounded theory }\end{array}$ & $\begin{array}{l}\text { - Hermeneutical circle as a } \\
\text { key interpreting device but } \\
\text { not reducible to a method } \\
\text { - Using source criticism for } \\
\text { establishing prospects and } \\
\text { limits of empirical material }\end{array}$ \\
\hline Key references & $\begin{array}{l}\text { Eisenhardt, 1989; Glaser \& } \\
\text { Strauss, } 1967\end{array}$ & $\begin{array}{l}\text { Gioia et al., 2013; Corley \& } \\
\text { Gioia, 2004; Glaser \& } \\
\text { Strauss, } 1967\end{array}$ & $\begin{array}{l}\text { Historical research after } \\
\text { "linguistic turn"; Gadamer, } \\
\text { 2013; Alvesson \& Kärre- } \\
\text { man, } 2007\end{array}$ \\
\hline
\end{tabular}


Table 2: Characteristics of Landis \& Gyr and Switzerland during the Period of Study

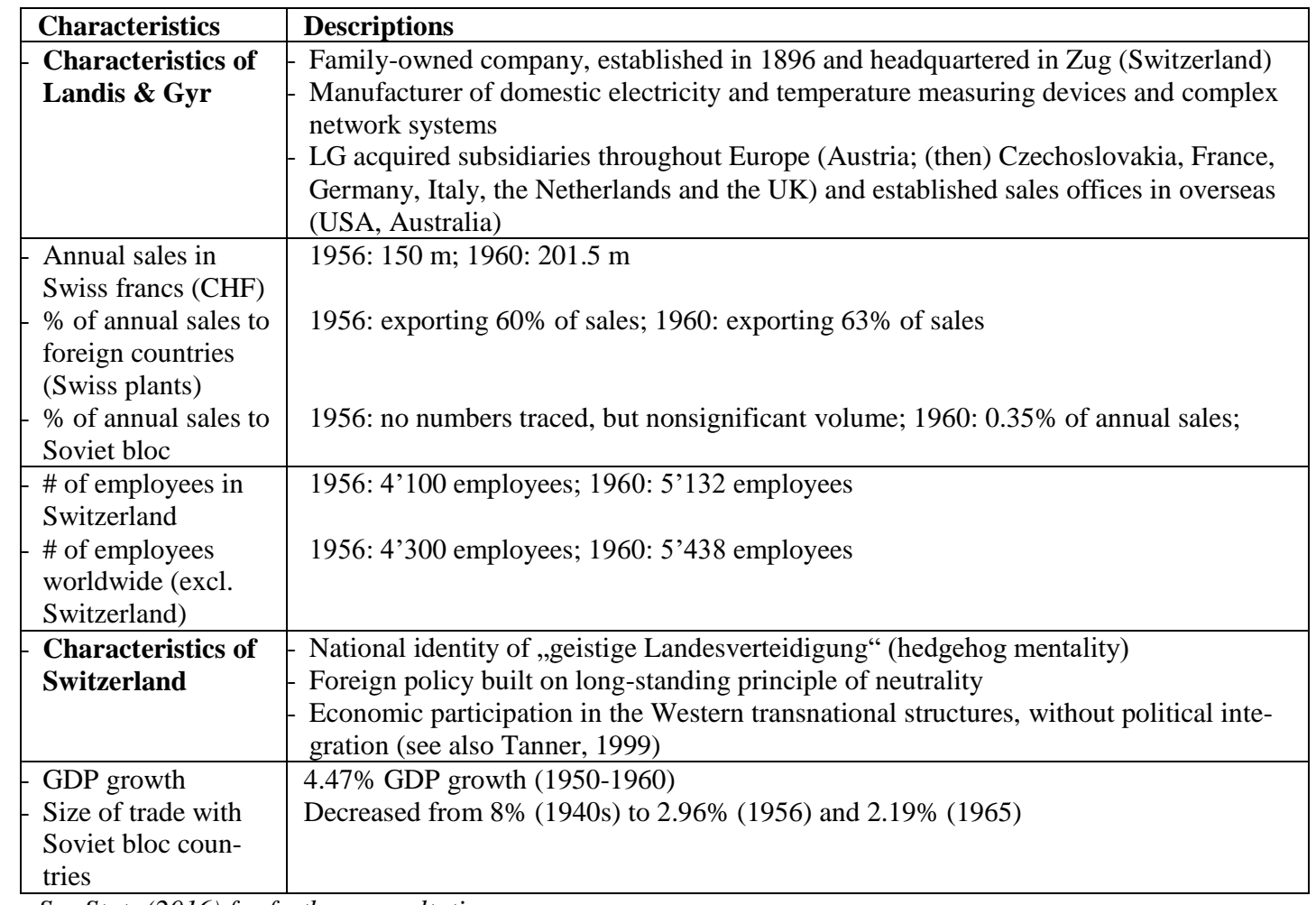

See Stutz (2016) for further consultation.

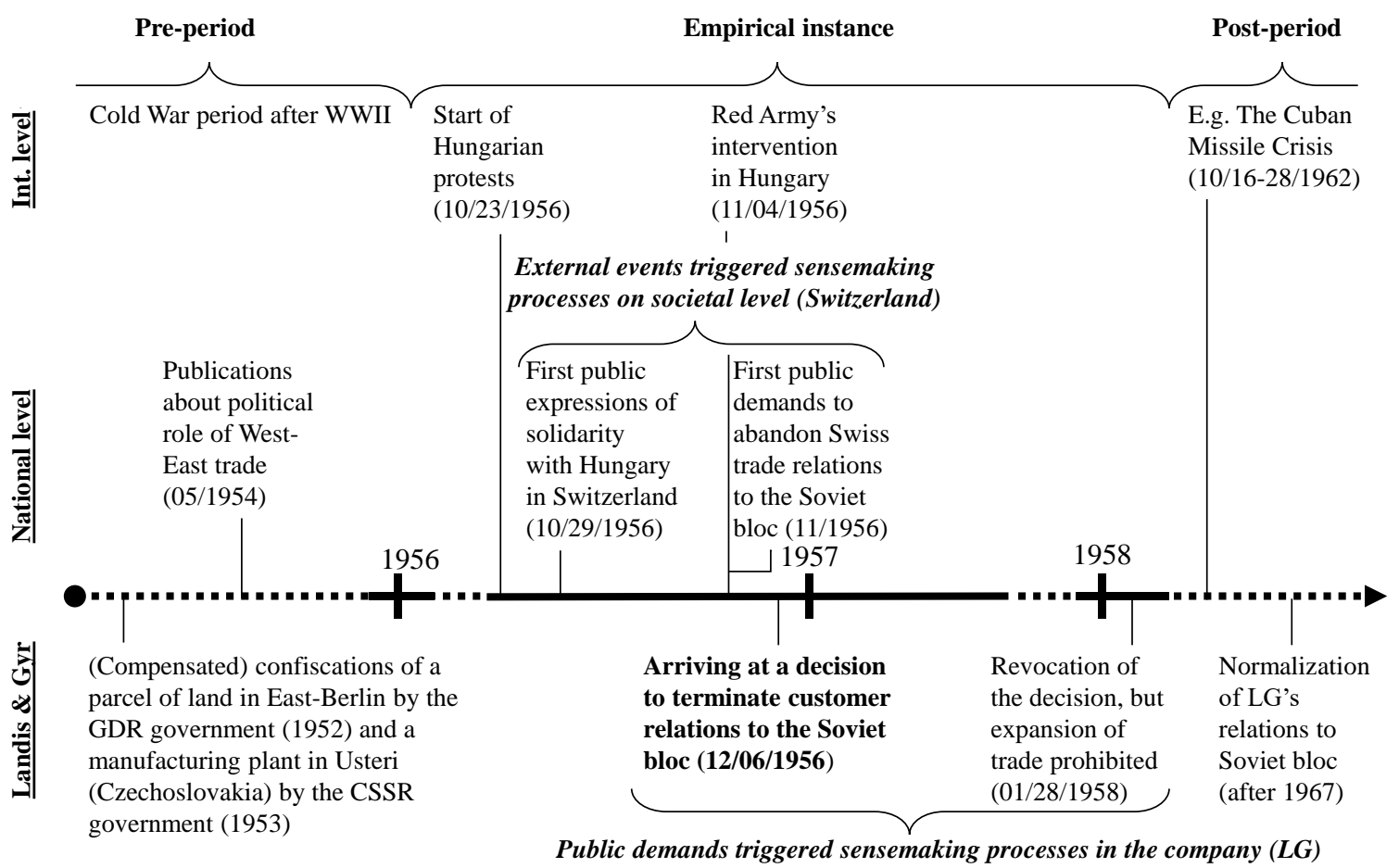

Figure 1: Timeline of Unfolding Events on Organizational, National and International Level 
${ }^{1}$ Engaging with Hans-Georg Gadamer's work was suggested by a reviewer. It is greatly appreciated.

2 The company archive is preserved in the public repository of the Archives of Contemporary History (AfZ) in Zurich. The records are searchable in the virtual reading room (http://onlinearchives.ethz.ch). 